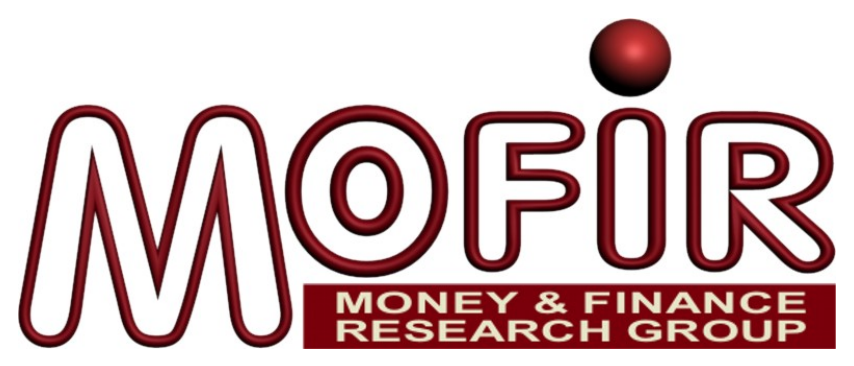

\title{
Do Inter-Firm Networks Make Access to FinANCE EASIER? ISSUES AND EMPIRICAL EVIDENCE
}

\author{
Domenico Scalera
}

Università del Sannio

Alberto ZaZZaro

Università Politecnica delle Marche, Department of Economics $M o F_{I} R$ CFEPSR

MoFiR working paper $\mathrm{n}^{\circ} 25$

July 2009 


\title{
Do Inter-Firm Networks Make Access to Finance Easier? Issues and Empirical Evidence*
}

\author{
Domenico Scalera \\ Università del Sannio \\ Alberto Zazzaro \\ Università Politecnica delle Marche
}

June 2009

Forthcoming in: Contractual Networks, Inter-Firm Cooperation and the Small Business Act, edited by Fabrizio Cafaggi Cheltenam: Edward Elgar.

\begin{abstract}
Does participation in inter-firm networks make access to credit easier for firms? Is finance a motivation driving the formation of inter-firm networks? During the last twenty years these two questions have been hotly debated by economists both theoretically and empirically. In this paper, we selectively review the literature on inter-firm networking, internal capital markets and access to external credit.
\end{abstract}

\footnotetext{
* A preliminary version of this paper was presented at the workshop "Contractual Networks, Inter-Firm Cooperation and the Small Business Act" held at the European University Institute, Fiesole, Italy on 31 October - 1 November 2008. We wish to thank Fabrizio Cafaggi, Marcello Messori and workshop participants for comments and discussions.
} 


\section{Introduction}

A common, implicit assumption in many textbook presentations of corporate finance and lending decisions is that firms are single-handed, without any sort of stable nexus with other firms ${ }^{1}$. However, it is frequent to observe real-world firms forming networks with numerous multilateral links based on formal and informal, hierarchical and non-hierarchical ties ${ }^{2}$. In the presence of such a contrast between theory and practice, the crucial question is whether or not the assumption of stand-aloneness curbs the full understanding of firms' financial problems; in other words, whether by thinking of economic agents in isolation we miss something important from the standpoint of financial analysis and bank-firm relationships.

All in all, the answer emerging from fifteen years of intense theoretical and empirical research on these issues is broadly affirmative. The objective of this chapter is to provide a selective review of the literature on inter-firm networks and access to finance, giving an account both of the main accomplished results and the issues still unresolved. In particular, our discussion will be organized around two main questions. In Section 3 we inquire whether finance is a motivation driving the formation of inter-firm networks. Section 4 explores whether inter-firm networking increases the availability of financial resources for network members, and if so, through which channels.

Given the wide range of meanings with which the word "network" has been used in the scientific literature, and the variety of inter-firm networks existing in the real world, we first touch upon the very expression of inter-firm networking by providing a classification of possible ways to form and organize a network. This will be our task in the next section. To conclude, in Section 5 we draw attention to some open questions which can form a research agenda for the future.

\section{Inter-firm networks: a taxonomy}

Drawing on the terminology of graph theory and network analysis, a social network is a set of agents (vertexes) connected to each other by relationships (edges) related to some specific activities or goals (Jackson 2008). In the case of inter-firm networks, agents are legally independent firms, while links and their motivations can be of various nature, like contracts, ownership, community, ethnicity, family, personal or political connections. This gives rise to an enormous variety of possible organizational forms of inter-firm networking.

\footnotetext{
${ }^{1}$ Distinguished examples include Copeland and Weston (1992), Brealey and Myers (2003) and Freixas and Rochet (1997).

2 The worldwide importance of inter-firm networks, shaped as formal business groups, alliances or political connections, has been testified for example by La Porta et al. (1999), Anand and Khanna (2000), and Faccio (2006).
} 
Starting at least from the 1980s, great research efforts have been made to understand the nature and role of inter-firm networks, especially in managerial and organisational sciences, sociology and transaction-cost economics ${ }^{3}$. In a Coasian perspective, inter-firm networks can be viewed as a hybrid form of organization, half way between the impersonal market guided by the price mechanism and the hierarchical firm guided by a system of power and commands (Powell 1990; Kali 1999; Menard 2004; Cafaggi 2004, 2008). From this standpoint, a useful criterion to classify inter-firm networks can be based on the governance mechanisms regulating networks.

Networks are stable coordination devices for economic transactions among members, grounded on formal and informal links, and hierarchically or jointly governed with a common goal. Firms can be connected in the network by a nexus of bilateral or multilateral contracts, without providing for a third, independent institution devoted to the network's management (as in the case of sub-contracting). However, it is also possible that one of the members pulls the strings of the whole network (as in the case of holding companies) or that an institution is created to represent the network itself (such as firm consortia or R\&D joint ventures).

In Figure 1 we give a branch-graph representation for a possible governance-based classification of inter-firm networks. Obviously, the same type of network can appear in different branches. For example, a joint venture created with the objective of developing a new technology/product can be entirely organized and regulated by contracts, with or without a leader, or it can bring about the constitution of a new joint-venture company leading the research project. Similarly, industrial districts can be hierarchically structured around one or more business leaders or can be formed by a multitude of firms on a par position. Further, interlock directorships and cross-ownerships can be formalized in binding voting agreements or can informally come into being.

Moreover, a firm can take part in more than one network at the same time: for example, outsourcers and sub-contractors could belong to the same community (industrial district, ethnic group) or joint ventures could be formed among firms belonging to business groups.

\section{[Insert Figure 1]}

\section{Is there a finance motive for inter-firm networks?}

Like any other way of organizing economic transactions, inter-firm networks arise - and their governance structure are selected - with the (explicit or implicit) objective to minimise costs of acquiring additional (material or immaterial) resources, in contexts characterised by uncertainty,

${ }^{3}$ Influential surveys of the literature on inter-firm networks may be found in Grandori and Soda (1995) and Menard (2004). 
incomplete information and opportunistic behaviour. Within the broad category of 'acquisition costs', we can distinguish on the one hand the costs of searching, assessing, contracting and enforcing the exchange agreements, and on the other the price of the needed resources. For example, Kranton (1996) focuses on searching, and suggests that a trading network arises as the optimal solution to the trade-off between the benefit of product variety guaranteed by market exchanges and the benefit of trading with a trustworthy partner pledged by a net of reciprocal exchanges. Kali (1999) instead considers the costs of contract enforcement and shows that when agents can cheat the agreement and courts enforce contract law inefficiently, business networks arise as a device to self-select honest entrepreneurs ${ }^{4}$.

In this perspective, finance may be one of the foremost resources missing at various moments of a firm's life, from start-up to innovation adoption or to getting through financial distress. In these crucial stages, establishing or participating in an inter-firm network can be an efficient way to mitigate the scarcity of financial resources. In some cases the network assumes the form of a financial company, like credit cooperatives or mutual loan guarantee societies, while in others it can be created by non-financial companies to reduce the cost of finance or to facilitate access to external financial markets. However, despite the obvious importance of finance for a firm's life, there are few formal theories that view finance as a motivation for interfirm networks. For the sake of presentation, we can sort these theories into three groups, according to the type of financial benefit they focus on: (i) the availability of financial resources; (ii) the provision of mutual debt guarantees; (iii) the flexibility of resource allocation.

\subsection{Availability of financial resources}

The traditional view of pyramidal groups considers this form of business organization as a way to separate control from cash-flow rights. In other words, pyramids allow an economic entity (typically, but not necessarily, a family) to maintain ultimate control over a firm by a chain of indirect ownerships requiring only a small direct monetary disbursement.

In a recent paper, Almeida and Wolfenzon (2006) dispute this view on the grounds that in many groups the separation between control and cash-flow rights is very small and that there are other devices (for example, dual-class shares) that allow the controlling family to deviate from the one-share-one-vote rule as well, without forming a formal group. As an alternative, they develop a theory in which poor investor protection, coupled with imperfect capital markets, can explain

\footnotetext{
${ }^{4}$ Avoiding opportunistic behaviour is also the rationale for social networks according to Taylor (2000). In a similar vein, Greif $(1989,1993)$, on the basis of well-grounded historical evidence, suggests that the rationale of the Maghribi, the ancient coalition of traders active between the $11^{\text {th }}$ and $12^{\text {th }}$ century in the Mediterranean area, has to be sought in the prohibitively high costs of enforcing formal overseas commercial agreements by law.
} 
both the choice of the pyramidal group's form and the existence of the group itself. To grasp the intuition behind their model, let us consider a new firm $\mathrm{B}$ requiring an investment $\mathrm{V}$ to be started up within a group formed by another firm A. The investment can be funded with external and internal financial resources. With regard to the latter, the controlling shareholder (family) of firm A may either use only part of firm A's retained earnings which she can access and therefore maintain direct control over B (horizontal group), or may put the whole retained earnings produced by $\mathrm{A}$ in $\mathrm{B}$ and establish a pyramidal group. When the risks of cash flow diversion are low, the acquisition of $\mathrm{B}$ could be funded by resorting to external finance at a fair price. In this case, the controlling family will prefer to form a horizontal group in order not to share firm B's revenues with firm A's minority shareholders. By contrast, when minority shareholders are weakly protected by law, and the risk of cash-flow diversion by the controlling family is quite high, external finance can be so costly as to make it insufficient to fund the new business. In this case, the pyramidal structure allows the controlling shareholder to tap more internal financial resources and also to share the loss in the value of B's securities with firm A's minority shareholders.

A similar reasoning can also explain the very formation of a group. Assume that firm B can be run more efficiently by another new entrepreneur. This entrepreneur, however, does not have any accumulated financial resources and has to fund the whole investment $\mathrm{V}$ by external finance. When shareholder protection is low, the entrepreneur cannot raise enough cheap finance and firm B might be more profitably started up by the family controlling A that can access its retained earnings and form a pyramid.

The possibility to gain access to network internal capital flows when financial constraints are binding underpins the theory of R\&D firm alliances proposed by Fulghieri and Sevilir (2003). In their model a research unit and a downstream firm can cooperate to produce a marketable innovation. They can cooperate as separate entities, but can also decide to integrate R\&D and output production in the downstream firm. In the spirit of incomplete contract theory (Hart 1995), the optimal allocation of property rights on innovation depends on the relative contribution of the two parties to innovation production. Fulghieri and Sevilir assume that property rights on innovation should be attributed to the $\mathrm{R} \& \mathrm{D}$ unit, but that this unit does not have enough financial resources to self-fund investments. However, recourse to external finance introduces a moral hazard effect which might reduce the effort of the research unit in the R\&D race. In this case, an alliance between the research and downstream units could be an effective alternative through which to guarantee the availability of financial resources and avoid the adverse incentive effects. 


\subsection{Mutual debt guarantee}

A second group of papers focuses on explicit or implicit forms of cross-debt guarantee which the network can provide its members so as to reduce asymmetric information problems and gain easier access to bank debt. Ghatak and Kali (2001) consider the case of a credit market plagued by adverse selection. In this case, if firms have no collateralisable wealth but obtain better information about each other than banks do, debt contracts providing for a mutual guarantee across a number of borrowers might be used by banks as a sorting device to exclude negative present value projects and attract low-risk borrowers. Once moral hazard is added, and success probabilities of funded projects are assumed to depend on the reciprocal monitoring effort of group members, Ghatak and Kali show that debt cross-holding has to go along with equity crossholding to allow banks to separate bad and good borrowers through the supply of a menu of contracts.

Busetta and Zazzaro (2009) reverse Ghatak and Kali's assumptions on information and wealth, and analyze the effects of implicit cross-debt guarantees should borrowers be endowed with a limited amount of collateralisable wealth, but not have any informational advantage over banks. In the context of a monopolistic credit market with adverse selection, they show that mutual loan guarantee societies may arise by pooling either safe only or alternatively both safe and risky borrowers. To grasp the economic intuition of their model, assume that borrowers do not have enough wealth to satisfy the collateral requirement of the loan contracts the bank designs to self-separate safe and risky projects. Moreover, assume that the share of entrepreneurs endowed with safe projects is small enough to make the interest rate on the optimal pooled contract offered by the bank so high as to exclude these entrepreneurs from borrowing. By pooling their wealth and establishing a mutual loan guarantee society, safe entrepreneurs can obtain access to credit with a probability which depends on the gap between the available wealth and collateral requirement, that is on the percentage of members that can obtain the required collateral from the guarantee society. Of course, the benefits they can obtain depend on whether or not risky borrowers find it profitable to join the society. If not, the society is formed only by safe entrepreneurs. However, if the benefit of sharing the risk of losing wealth with safe entrepreneurs outweighed the costs of a positive probability of being rationed, risky entrepreneurs would participate in the mutual society. In this case, a non-assortative society forms only if for safe borrowers the cost of credit rationing is high enough to outweigh the negative effects of sharing the credit risk with bad partners.

Another contribution focusing on cross-debt guarantees is that of Kim (2004), who draws inspiration from the experience of Korean business groups (chaebols) in which bank loans are a very important source of finance and cross-debt guarantee contracts are widely practised. Kim 
shows that inter-firm conglomerations can arise with the aim of maximising the likelihood to be bailed-out by banks in the case of financial distress. In fact, when information disclosure is weak, banks might optimally choose to bail out firms so as not to risk losing good borrowers only momentarily in trouble. As a consequence, firms have an incentive to form a group which, by cross-guaranteeing debt payments of members, obscures information on their state of health and minimizes the risk of liquidation.

Finally, Hainz (2006) considers the case of strategic default in competitive credit markets, and shows that the formation of a group between two vertically integrated firms linked by sequential cost-reducing investments may allow banks to design self-enforcing loan contracts. The reason is that when deciding about defaulting on the loan obtained in the first period, the firm takes into account that the bank would deny credit to the other firm in the subsequent period and therefore that the externalities connected to its cost-reducing investment would be lost.

\subsection{Allocation flexibility}

The idea that internal capital markets (henceforth ICMs) generate strategic benefits and costs for group members with respect to stand-alone rivals in product markets has been widely investigated $^{5}$. Recently, Mathews and Robinson (2008) and Robinson (2008) have built on this idea to analyse the incentive to form conglomerates or inter-firm alliances. Their analysis is based on the trade-off between resource flexibility provided by the ICM and the possibility granted by stand-aloneness to commit to a capital allocation and write enforceable contracts with outside investors. In particular, Mathews and Robinson (2008) consider the case of a downstream firm H that has to decide on the integration of an upstream firm A competing for an innovation with a stand-alone firm B. When product market uncertainty is low, the existence of ICMs can drive the stand-alone upstream firm $\mathrm{B}$ to predatory capital raising to discourage $\mathrm{H}$ from funnelling internal resources towards A. By contrast, when product market uncertainty is high and innovation expected returns low, the flexibility of ICMs causes a classical deep-pocket effect, thereby deterring $\mathrm{B}$ from entering the market. The decision of $\mathrm{H}$ on whether to integrate $\mathrm{A}$ depends on the relation between H's downstream industry and the upstream industry. If they are unconnected, $\mathrm{H}$ integrates A mainly when the flexibility of the ICM acts as a deterrent to entry for $\mathrm{B}$. If instead $\mathrm{H}$ benefits from innovation in the upstream industry, whichever firm introduces it, entry deterrence is costly for $\mathrm{H}$ because, should $\mathrm{A}$ fail to innovate, it cannot acquire the innovation from B. In this case, ICM flexibility leads towards integration only if uncertainty on

\footnotetext{
5 Amongst others, see Matsusaka and Nanda (2002) and Cestone and Fumagalli (2005).
} 
the product market size is particularly high. However, in such circumstances, $\mathrm{H}$ and A could prefer to sign a strategic alliance by which they can obtain physical synergy, foregoing the flexibility of ICM and neutralizing the entry-deterrence effect.

\section{Is finance less binding for network members?}

\subsection{Theory...}

Whatever the motivation for firm networking, belonging to a network can have major effects on the availability of financial resources and access to external capital markets for its members. Although these effects can be expected to vary from network to network, we can distinguish some common channels through which participation in an inter-firm network matters for corporate finance and relationships with external lenders (see Table 1). First, once a network is formed, firms can establish an internal capital market ${ }^{6}$. Whatever the type of link connecting firms in the network and whatever the form of governance selected, the opportunity for firms to extend credit to each other is definitely greater within a formal or informal network than outside. Indeed, network members have natural informational advantages over non-members about the quality (i.e. expected return, risk, etc.) of other members' investment projects. This greater information availability can lead members to lend to each other at better conditions than those granted on external capital markets, but can also act as a sort of quality certification towards external lenders (peer-screening and monitoring effects) that are therefore more prone to lend to network members. In addition, network members have a direct interest to support actions and performances of their partners either by lending fresh financial resources or by deferring takings (trade credit) or also by offering explicit/implicit personal guarantees to facilitate the collection of external debt (Friedman et al. 2003).

Other channels through which networking can affect access to external credit comprise network reputation, the possibility of collective actions against lenders and the cross-guarantee of debt. To the extent that information on borrowers is scarce and imperfect, lenders can use information accumulated on the network and its components to complement the creditworthiness assessment of one of its members. This can produce good or bad reputation effects, leading to positive or negative discrimination in credit markets with regard to loan conditions and probability of rationing (Ferguson and Peters 1997; Scalera and Zazzaro 2001). Beside reputation, the network also endows its members with bargaining power against external

\footnotetext{
${ }^{6}$ A review of theoretical and empirical studies on the internal capital market may be found in Stein (2003).
} 
lenders. This bargaining effect can directly benefit each network member in its relations with lenders, or can cause so-called double intermediation, in which one (or a few) component of the network gets into debt on external capital markets and then lends or transfers the collected financial resources to the other network members (Dei Ottati 1994; Bianco and Nicodano 2006). Finally, lenders can consider it less risky to provide credit to subjects that can count, implicitly or explicitly, on their debt being guaranteed by part of the other network members and for which access to the ICM reduces the likelihood of bankruptcy (Gopalan et al. 2007).

[Insert Table 1]

On the other hand, network membership can also adversely affect access to credit. For example, external lenders may realistically expect the risk of contagion crises among network members to be greater and therefore be willing to buy their assets only at a discount. Also, the very existence of an ICM, if combined with conflict of interests within the network, can increase the informational opacity of individual members and make it riskier for lenders to finance their activity.

Conflict of interests within inter-firm networks can materialize in different forms. First, in hierarchically organized networks, of which pyramidal groups are the archetype, the leader of the network can tunnel resources out of other components for its own benefit (Johnson et al. 2000). Similarly, when the network is characterized by principal-agent relationships, the principal can use the ICM to produce an inefficient allocation of resources so as to reduce influence (rent-seeking) activities and increase cooperative behaviour (Rajan et al. 2000; Scharfstein and Stein 2000; Wulf 2005). Finally, individual network members can free-ride on the interest that other members have in bailing them out in the event of financial distress. This expectation produces a sort of soft budget constraint that, as is well understood in the literature, reduces the effort put in the business and induces inefficient behaviour by network members (Roland 2000). Anticipating the effects of tunnelling, rent-seeking and free-riding, external lenders can prove less willing to fund (non-leader) network firms than stand-alone businesses, thus charging higher interest rates and influencing optimal corporate financing decisions.

\section{$4.2 \ldots$ and empirical results}

While it is difficult to provide evidence on the motivations driving the formation of inter-firm networks, a large body of literature has sought to analyse and disentangle the contrasting effects that network membership may exert on firms' financial constraints. In this section we give an account of this literature. Given the large and continuously increasing number of contributions, we can forcefully provide only a very selective, non-exhaustive review of the available evidence, 
which for the sake of neatness we split into two parts. While the former focuses on business groups and conglomerates, covered by the majority of contributions, the latter concerns other types of formal and informal networks, for which evidence is much scarcer.

\subsubsection{Business groups and conglomerates}

\section{A. Investment sensitiveness to cash flow and credit rationing}

Ever since the seminal contribution of Hoshi et al. (1991) on Japanese keiretsu, many studies, with reference to several countries, have found that belonging to an inter-firm network induces a reduction in the firms' investment sensitivity to cash flow ${ }^{7}$. This evidence is usually interpreted to support the hypothesis that group firms are less financially constrained than stand-alone firms as the former can benefit from access to an ICM that complements the external sources of finance.

However, the lower sensitivity of investment to cash flow is consistent not only with the hypothesis that ICMs allow network members to reallocate funds to each other at cheaper terms, but also with the idea that banks are more prone to lend to borrowers that can benefit from the implicit guarantee of other firms by virtue of the cross-debt guarantee. In the former case, group firms would be less constrained due to the complement of external finance with internal finance. In the latter, the supply of external funds would be larger for group firms, thus alleviating their financial constraints. To disentangle these two different effects, some authors have considered cross cash flow sensitivity, i.e. the responsiveness of investment to the cash flow of another network member. For example, Shin and Stultz (1998), looking at corporate segments of large US firms, find that the investment by each segment significantly depends on the cash flow of the other firm's segments. Cross cash flow sensitivity is investigated as well by Lamont (1997), who detects that negative shocks which strike one segment (petroleum) come to significantly affect other segments of the same firm in terms of reduced actual investments and larger finance costs. In both these cases the positive effect of network participation turns out to be connected to the functioning of internal capital markets. Conversely, considering a sample of listed Indian companies, Gangopadhyay et al. (2003), found i) that group affiliated firms have little investment sensitivity to their own cash flow and ii) that they are less constrained than stand-alone

\footnotetext{
7 Among the many, see Hermes and Lensink (1998) for Chile; Shin and Park (1999) for South Korean chaebol; Schiantarelli and Sembenelli (2000) for Italy; Perotti and Gelfer (2001) for Russia; Samphantarak (2003) for Thailand, and Castañeda (2002) for Mexico. The latter also highlights the role of close banking ties in explaining smaller sensitivity of investment to cash stock. Some major exceptions to the result of a lower cash flow investment sensitivity for group firms are given by Khanna and Palepu (2000) and Rejie et al. (2008), both referring to Indian business groups, as well as by Reimund (2002) who studied a sample of 220 German corporate groups. In the former cases strong investment to cash flow sensitivities for both group and non-group firms are found, but no significant difference between them. In the latter paper, empirical evidence indicates that investment - cash flow sensitivity for firms heavily using ICMs is even higher than for firms relying more on bank financing.
} 
counterparts thanks to better access to external finance, as shown by the comparison on the composition of corporate debt.

A different group of contributions seeks to assess the impact of network membership on the likelihood of firms being credit-rationed by resorting to other indicators, such as the ratio of overshoots to granted facilities or the firms' self-assessment of credit rationing. Once again, the most common result is that networks tend to lighten credit rationing. For example, Deloof (1998) detects looser credit constraints for Belgian firms whose investments are partly financed on an ICM, while Lizal and Svejnar (2002), studying a sample of Czech manufacturing firms between 1992 and 1998, show that companies belonging to groups are less credit-rationed than standalone and cooperative firms. With reference to Italy, Marchionne and Zazzaro (2008) find that belonging to a group in itself does not have a significant impact on the probability of being rationed by banks. However, affiliated firms (but not holding and parent firms) emerge as less rationed when the group size is sufficiently large (over 27 members), hence suggesting that diversification and guarantee effects may be at work.

\section{B. Firms' capital structure}

In principle, network membership could affect the leverage ratio in different ways. For example, it may favour the substitution of external debt with internal funds supplied by ICMs or it may lead banks to reduce loans when participation in the network increases opaqueness. In practice, the most common finding of a lower leverage for groups' firms has usually been interpreted as an effect of ICM functioning. For example, Desai et al. (2004) argue that foreign affiliates of U.S. multinational corporations have relatively low leverage ratios since they use parent debt as a substitute for external debt, especially in host countries where access to external financing is limited or expensive. Dewaelheyns and Van Hulle (2008) use a sample of 553 subsidiaries belonging to 253 Belgian private business groups to show that they have a substantially lower bank debt compared to stand-alone companies. They also provide evidence that when group overall debt level mounts, they increasingly locate bank borrowing in subsidiaries with lower costs of external financing (i.e. large subsidiaries with important collaterizable assets). Working on Italian data, Piga (2002) finds that membership of a group is negatively correlated to leverage. Marchionne and Zazzaro (2008) confirm this result, provided that the group size (hence the ICM) is fairly large.

In contrast, other studies detect different relationships between networking and capital structure. Kim et al. (2006), studying Korean firms' capital structure before the 1997 crisis, find that chaebol affiliates are more indebted than stand-alone firms and explain this finding with the 
cross-debt guarantees supplied by the other chaebol members, which allow banks to reduce loan riskiness. Manos et al. (2007) present evidence on 1,652 quoted non-financial firms in India and show that both mean and median leverage of group-affiliated firms are higher than the counterpart measures for non-affiliated firms. They also find that size and growth do not matter for the capital structure of group-affiliated firms, whereas they are critical factors for independent firms, thus showing that banks use information on the participation in a network as a substitute for other indicators of profitability and risk. Examining data from US multinational company affiliates in 62 countries, Aggarwal and Kyaw (2008) find that the capital structure of such firms is sensitive to country-specific features. In countries with poor institutional features, affiliates substitute external debt with parent debt: where taxes and credit availability and creditor protection are low and political risk is high, multinational companies have lower external debt and bear higher interest costs.

Beside the quarrel on the impact of networking on debt ratio, other interesting issues have been covered by the literature. For example, some papers have considered possible differences in firms' financial structure connected to the role of firms inside the network. Since banks can anticipate the negative effects of conflict of interests in the network, leader firms may find it profitable to charge themselves with a higher level of debt than other members to signal their commitment not to carry out a predatory behaviour. This argument can rationalise the results of Piga (2002), Bianco and Nicodano (2006) and Marchionne and Zazzaro (2008), who find that in Italy holding firms show higher leverage than affiliates. Gopalan et al. (2007) consider another possible way in which the firm-bank relationship may be influenced by network membership: they show that outside debt financing is heavily affected not by the network's membership in itself but rather by recent performance (and especially bankruptcy) of other group members. This finding highlights the weight of group reputation in the presence of scarce information on single firms. It also gives a rationale for ICMs to support weak members since their bankruptcy yields a negative reputation externality on the other healthy firms of the network both in terms of higher financial costs and rationing.

\section{The bright and dark sides of ICMs}

An extensive theoretical literature on ICMs highlights their relative virtues and drawbacks. The most popular arguments in favour of ICMs have been set forth in seminal contributions by Alchian (1969), Williamson (1975), Gertner et al. (1994) and Stein (1997): informational advantages of headquarters with respect to external lenders, increased monitoring incentives, 
better asset redeployability, selective intervention and so n $^{8}$. No less persuasive, however, are the arguments on ICM inefficiencies. These are mostly connected to influence activities (Scharfstein and Stein, 2000; Wulf, 2005), incentive problems (Rajan et al., 2000), bureaucratic attitude (Shin and Stultz, 1998) and conflict of interests among network members (Johnson et al. 2000).

Just as the theory offers very heterogeneous results, empirical studies are also far from conclusive. Hinging on different indicators, several incline towards a positive judgement on ICM efficiency. According to Perotti and Gelfer (1998), financial reallocation inside groups seems to be mainly driven by the aim of alleviating financial constraints rather than opportunistically transferring value across firms, whence they conclude that "group firms allocate capital better than independent firms". In the same vein, Khanna and Tice (2001), focusing on the discount department store business, show that in response to a market shock, diversified firms' capital expenditures are more sensitive to the productivity of their business so that "internal capital markets function well, as transfers are away from the worsening discount divisions". The evidence provided by Maksimovic and Phillips (2002) is consistent with the hypothesis of wellfunctioning internal capital markets as well. By using plant-level data from manufacturing firms, they show that a positive demand shock to a conglomerate division with low productivity relative to its industry brings about a larger growth of the conglomerate's other divisions. In the same vein, Khanna and Yafeh (2005), relying on a large database spanning 12 emerging market countries, outline how ICMs perform a "liquidity smoothing" role inside business groups, thereby alleviating financial constraints arising in imperfect capital markets ${ }^{9}$.

However, a number of studies reach radically different conclusions. Regarding conglomerates, some of the first empirical contributions on the issue of ICM inefficiency are due to Lang and Stultz (1994) and Berger and Ofek (1995), who provide evidence for a negative difference (the so-called conglomerate discount) of around 15\% between a conglomerate's Tobin's $q$, measured by a weighted average of the divisional $q$ s, and mean Tobin's $q$ of singlesegment firms operating in the same industry, and show that cross-subsidization and inefficient investment contribute to the discount. Since then, abundant evidence has been supplied

\footnotetext{
8 Other possible benefits connected to ICMs, like the chance it gives to overcome the inability of external finance to support high-risk activities such as innovation (see, among many others, Himmelberg and Petersen, 1994) are not considered here.

9 Similar results are also obtained by Samphantharak (2003), who worked on a sample of 907 large firms and 117 business groups in Thailand between 1993 and 1996, and Lee et al. (2009) who, with reference to Korean chaebols, find that ICMs attenuated the financial constraints of the affiliated firms and efficiently allocated capital during the early 1990s. The latter paper also points out that the financial crisis of 1997 significantly worsened ICM functioning: "chaebol firms' coordinated attempts to achieve healthier financial structures in the wake of the crisis take place at the expense of investment efficiency".
} 
supporting the hypothesis of ICM inefficiency. This view is shared, among many others ${ }^{10}$, by Rajan et al. (2000): studying a large sample of US conglomerate segments, they estimate financial transfers made and received by each segment to show that "diversified firms transfer more to divisions with poor opportunities (...) in contrast to efficient internal market models". More recently, Ozbas and Scharfstein (2009) found that unrelated segments of conglomerate firms exhibit lower $q$-sensitivity of investment than stand-alone firms and also invest more (less) than their stand-alone counterparts in low- $q$ (high- $q$ ) industries.

Starting from the awareness that ICMs supply "many examples of looting of firms by their controlling shareholders, [assets] transferred out of companies, profits siphoned off to escape creditors, and troubled firms in a group propped up using loan guarantees by other group members" (Johnson et al. 2000), another strand of the empirical literature has sought to test the relevance of possible conflicts of interest and their negative effects on finance allocation inside a network. For example, Bertrand et al. (2002) show that within Indian business groups tunnelling is a significantly widespread phenomenon. The case of propping is documented by Friedman et al. (2003) who find it particularly significant in high leverage groups, since propping is used as a device to make debt attractive to investors in countries with weak legal systems. More recently, Gonenc and Hermes (2008) and Bae et al. (2008) investigated propping respectively in Turkish and Korean business group firms, supplying further evidence for its existence. A different effect of the conflict of interests between owners and minority shareholders is highlighted by Faccio et al. (2003). They consider data from 14 European and East Asia economies and find that holding companies induce subsidiaries to over-borrow and bear bankruptcy costs to expropriate minority shareholders. Similarly, Gopalan et al. (2007) suggest that in Indian groups parent firms tend to transfer resources to weak subsidiaries and possibly bail them out to avoid negative spillovers on the other members.

\subsubsection{Subcontracting, industrial district and other networks}

\section{A. Contractual networks}

As already stated, the empirical evidence on relationships between participation in networks other than business groups and corporate finance is still scant. Concerning contractual networks, some attention has been devoted to studying the effects of trading relationship such as outsourcing-

\footnotetext{
${ }^{10}$ Similar results are found by Scharfstein (1998) in a sample of 165 diversified US conglomerates, Mullainathan and Scharfstein (2001) with reference to the US chemical industry, Natividad (2009) for the US motion picture industry and Gautier and Hamadi (2005) who consider Belgian holding companies. Finally, Rejie and Rezaul (2008) provide evidence on Indian business groups to show inefficient profit redistribution, more pronounced for groups of larger size and greater corporate control, which causes group-affiliated firms to underperform.
} 
subcontracting chains on trade credit ${ }^{11}$. For example, McMillan and Woodruff (1999), working on a survey of private firms in Vietnam, find that larger trade credit to customers is associated to longer duration of trading relationships and that network customers receive more credit. A further interesting finding of this paper is that, since trade credit suppliers use the borrower's leverage ratio as a measure of creditworthiness, recipients of bank loans turn out to receive on average more trade credit than others. In a similar vein, the investigation of Fafchamps and Minten (1999) points out that belonging to an inter-firm network of relational contracting increases the availability of trade credit and reduces external debt, by making it easier to collect information and sanction customers reneging on deals.

However, other recent papers reach more sceptical conclusions. Studying a sample of small and medium enterprises in India, De and Singh (2009) find that the role of business relationships as well as social relationships in inter-firm credit market is limited. Kumar and Subrahmanya (2008), again with reference to India, show that local SMEs subcontracting for transnational corporations enjoy large benefits from knowledge transfer, business volume, superior work culture, reputation and quality improvement, but at the same time the assistance for their financial needs is negligible.

The consortium is another type of contractual network which has attracted some attention in the literature. In particular, some studies are devoted to assessing the role played by mutual loan guarantee societies (MLGSs) in favouring access to bank credit by micro and small enterprises ${ }^{12}$. Econometric evidence on the impact of MLGSs on SME borrowing is broadly restricted to the case of Italy, a country where this type of consortium is very widespread. Columba et al. (2008) find that members of MLGSs enjoy lower interest rates and default rates with respect to nonMLGS firms and that this beneficial effect is stronger in the relatively less developed regions of southern Italy and decreasing when the number of members exceeds a threshold. These finding are confirmed by Sabetta (2009), who shows that MLGS intermediation allows a reduction in the cost of credit especially for southern firms. Busetta and Presbitero (2008), instead, focus on the internal functioning of an MLGS and show that both the interest rate charged by banks and the likelihood of members being credit rationed decrease with the share of loan covered by the MLGS guarantee.

\section{B. Non-contractual networks}

\footnotetext{
${ }^{11}$ Some have also examined the connection between group participation and trade credit. For example, Deloof and Jegers (1999) use a sample of 661 large non-financial Belgian firms to show that trade credit is an important alternative for short-term bank debt and even for long-term financial debt.

${ }^{12}$ For the sake of homogeneity, we restrict our attention to firms and do not consider households' consortia and their role in facilitating microfinance in developing countries.
} 
The idea that the actions of economic agents are crucially dependent on the social network within which they are embedded has been broadly accepted among sociologists and organizational theorists at least since Granovetter (1985), and it has been recently extended to include corporate finance issues.

The channels of influence identified by the "embeddedness approach" are numerous. For example, in a series of articles, Mark Mizruchi and co-authors argue that director interlocks and similarities in CEOs' backgrounds (e.g. schooling) may be key features in explaining firms' borrowing (Mizruchi et al., 2005); that having on their boards representatives of financial institutions allows firms to afford higher debt (Mizruchi and Stearns, 1994); that the source and amount of external finance are influenced by the type of representative sitting on the firm's board (Stearns and Mizruchi, 1993). Similarly, Khanna and Thomas (2009), using a sample of 457 Chilean firms, show that cross-ownership, equity ties and above all interlocking directorates yield high stock price synchronicity.

The impact of social relations between firms and banks representatives in allowing firms to enjoy better credit conditions in terms of interest rates, collateral and covenants is shown by Uzzi (1999) and Uzzi and Lancaster (2003). Diversely, Sorenson and Stuart (2001) emphasize the role of the network in the US venture capital market, showing that the extensive use of syndicated investing has significantly facilitated the diffusion of information, hence enlarging the space and scope of venture capital investments. Rao et al. (2001) show how belonging to a social network affects the choice of the market in which to be listed: they look at 1987-1994 data and detect that board interlocks are a fundamental factor to determine migration from NASDAQ to NYSE.

Another strand of literature on social relations and non-contractual inter-firm networks deals with access to credit in industrial districts (IDs) and other clusters. In spatially bounded contexts, credit conditions and the availability of financial resources are strongly conditioned by social factors such as trust, reputation and social sanctions against deceitful behaviour (Cafaggi and Iamiceli 2007). Especially in underdeveloped countries, such types of relations are valuable to overcome the lack of trust and the imperfect functioning of financial markets; but even in developed countries they can serve to relax firms' financial constraints and to grant lenders less risk thanks to more abundant and better information on borrowers. Beside the formal financial channels, ID firms often use informal credit, interlinked to other transactions like subcontracting, thus constituting a further device to reduce information problems of credit transactions (Dei Ottati, 1994). On the other hand, interlinked relations may contribute to increase the correlation among firms' economic and financial conditions and exacerbate contagion phenomena.

Empirical investigations on the issue are not conclusive. On one side, Russo and Rossi (2001) find that ID firms have both a lower cost of credit and a smaller probability of facing 
financial constraints. In the same vein, Rotondi (2005) and Ughetto (2007) show that firms located in IDs have easier access to external finance, even if this result is not robust when the analysis focuses on firms engaged in significant $\mathrm{R} \& \mathrm{D}$ activities. Consistent with this evidence, the finding of Alessandrini et al. (2008) shows that being localized in an ID reduces rationing probability by about $2.5 \%$ (and more than $5 \%$ if IDs have a functionally proximate banking system). On the other side, in Baffigi et al. (2000), ID firms turn out to be more constrained, as they present higher investment sensitivity to cash flow. This result is confirmed by Pagnini (2000) who detects a higher ratio of overshoots to granted facilities for ID firms. Finally, Guelpa and Tirri (2006) do not find evidence of significant differences in credit conditions and access to credit between ID firms and others.

Personal, family and ethnic ties are other typical examples of informal networks affecting firms' financing through information enhancement and reputation effects. Even in this case, the empirical assessment of the role of these ties in reducing financial constraints is controversial. For example, in aiming to explain access to credit for small businesses in the United States, Aaronson et al. (2004) investigate the role of ethnic connections in trade credit and find mixed evidence. In the case of Hispanic-owned businesses, belonging to the net is associated to larger trade credit than isolated firms, whereas this result does not hold for Black-owned firms. Shane and Cable (2002) wonder whether social ties are instruments to overcome information asymmetry between entrepreneurs and potential investors. Examining evidence on 50 hightechnology ventures, they evaluate the effects of direct and indirect ties between entrepreneurs and seed-stage investors on funding decisions, showing that these ties positively affect the likelihood of loan approval thanks to a process of information transfer. Conversely, Bruder et al. (2007), using data from a survey of 3,000 German firms, find that when controlling for observed risk factors and financial relationships as explanatory variables, no significant differences emerge in the probability of credit rationing between ethnic and native entrepreneurs.

Looking at the experience in developing and emerging countries, Fisman (2003) finds that African firms are twice as likely to obtain trade credit from suppliers from within the owners' ethnic communities as from outsiders. Biggs and Shah (2006) examine evidence on sub-Saharan African SMEs. They find that survival, performance and growth of these firms are strongly conditioned by the creation of private governance systems in the form of long-term business relationships and tight, ethnically based, business networks. In particular, a comparison between "outsiders" and networking firms shows that the latter enjoy easier access to credit. Silva et al. (2006) provide evidence on 114 Chilean firms to analyse the effects of social ties on the economic performance of firms affiliated to business groups. Their conclusions are that the possible benefits of family relations and interlocking of directors depend on the ownership- 
control structure: firm performance improves only when the concentration of voting rights is low or the voting rights of controlling shareholders are aligned with their cash-flow rights. By contrast, when the voting rights of controlling shareholders are substantially higher than their economic rights, social ties favour the expropriation of minority shareholders because actions that worsen the performance of the firm are less detrimental to controlling shareholders' interests. Finally, Batjargal and Liu (2004) study a sample of 158 venture capital decisions in the People's Republic of China and find that entrepreneurs' social capital has significant effects on investment decisions of venture capitalists, and particularly on contractual covenants, investment delivery and venture valuation.

\section{Concluding remarks: a research agenda}

A wide theoretical and empirical literature has in recent years analysed and tested the possible relationships between participation in inter-firm networks and corporate finance, seeking in particular to clarify whether a) finance can be in itself a motivation for the formation of networks and b) belonging to a network makes finance cheaper and/or access to external credit easier. This chapter selectively reviewed this literature. Although the conclusions are not entirely unambiguous, several possible reasons are spelled out why we should consider the financial motive as a major reason for setting up an inter-firm network. Likewise, a role for networks in favouring easier and cheaper access of firms to financial funds is widely recognised, through both the functioning of internal capital markets and a greater availability of bank credit.

A number of issues remain unresolved and constitute an extensive agenda for future theoretical and empirical research. For example, it is still unclear whether firm characteristics (dimensional or technological) affect the financial costs and benefits of either forming or participating in a network; whether formal and informal networks overlap; and whether network participation facilitates other network connections. Also, despite the work done to elucidate the effects of networks on corporate finance, further effort is needed to clarify the possible multifaceted consequences of networking on firms' capital structure and on the pecking order of financial sources. Finally, since the relation between institutional and environmental variables and the role and functions of inter-firm networks has barely been explored, we know very little on how the architecture of financial systems, the features of financial regulation and the degree of investor protection interact with a network's ability to relax its participants' financial constraints. 


\section{References}

Aaronson D., Bostic R., Huck P. and R. Townsend (2004), "Supplier relationship and small business use of trade credit" Journal of Urban Economics, 55(1), 46-67.

Aggarwal R. and Kyaw N.A. (2008) "Internal capital networks as a source of MNC competitive advantage: Evidence from foreign subsidiary capital structure decisions", Research in International Business and Finance, 22(3), 409-39.

Alchian A. (1969), "Corporate management and property rights," in Henry Manne (ed.), Economic Policy and the Regulation of Corporate Securities, Washington, DC, American Enterprise Institute.

Alessandrini P., A.F. Presbitero and A. Zazzaro (2008), "Banche e imprese nei distretti industriali”, in A. Zazzaro (ed.), I vincoli finanæiari alla crescita delle imprese, Roma, Carocci.

Almeida H. and D. Wolfenzon (2006), "A Theory of Pyramidal Ownership and Family Business Groups", Journal of Finance 61, 2637-81.

Anand B.N. and T. Khanna (2000), "Do firms learn to create value? The case of alliances", Strategic Management Journal, 21, 295-315.

Bae G.S., Y.S. Cheon and J.K. Kang (2008), "Intragroup propping: Evidence from the stockprice effects of earnings announcements by Korean business groups", Review of Financial Studies, 21(5), 2015-60.

Baffigi A., M. Pagnini and F. Quintiliani (2000), "Localismo bancario e distretti industriali: assetto dei mercati del credito e finanziamento degli investimenti”, in F.L. Signorini (ed.), Lo sviluppo locale, Roma, Donzelli.

Batjargal B. and M. Liu (2004), “ Entrepreneurs' access to private equity in China: The role of social capital”, Organization Science, 15(2), 159-72.

Berger P. and E. Ofek (1995), "Diversification's effect on firm value", Journal of Financial Economics, 37, 39-66.

Bertrand M., P. Mehta and S. Mullainathan (2002), "Ferreting out tunnelling: An application to Indian business groups”, Quarterly Journal of Economics, 117(1), 121-48.

Bianco M. and G. Nicodano (2006), "Pyramidal groups and debt", European Economic Review, 50(4), 937-61.

Biggs T. and M.K. Shah (2006), "African SMES, networks, and manufacturing performance", Journal of Banking \& Finance, 30(11), 3043-66.

Brealey R.A. and S.C. Myers (2003), Principles of corporate finance, McGraw Hill.

Bruder J., Neuberger D. and S. Raethke-Doeppner (2007), "Financial constraints of ethnic entrepreneurship: Evidence from Germany”, Thuenen-Series of Applied Economic Theory, paper 84. 
Busetta G. and A.F. Presbitero (2008), "Confidi, piccole imprese e banche: un'analisi empirica”, in A. Zazzaro (ed.), I vincoli finanziari alla crescita delle imprese, Roma, Carocci.

Busetta G. and A. Zazzaro (2009), "Mutual loan-guarantee societies in monopolistic credit markets with adverse selection: Do they act as a sorting device?”, mimeo, Universita' Politecnica delle Marche, Ancona.

Cafaggi F. (2004), "Il governo della rete: modelli organizzativi del coordinamento interimprenditoriale", in F. Cafaggi (ed.), Reti di imprese tra regolazione e norme sociali, Bologna, il Mulino,

Cafaggi F. (2008), "Contractual networks and small business act: Towards European principles", EUI Working Papers, Law 2008/15, Florence, European University Institute.

Cafaggi F. and P. Iamiceli (2007), Reti di imprese tra crescita e innovaz̦ione organizzativa. Riflessioni da una ricerca sul campo, Bologna: il Mulino.

Castañeda G. (2002), "Internal capital markets and financing choices of Mexican firms before and during the financial paralysis of 1995-2000", Inter-American Development Bank Research Network Working Paper R-451

Cestone G. and C. Fumagalli (2005), “The Strategic Impact of Resource Flexibility in Business Groups", RAND Journal of Economics, 36 (1), 193-214.

Columba F., L. Gambacorta and P.E. Mistrulli (2008), "Firms as monitor of other firms: mutual guarantee institutions and SME finance" MPR A Paper 14032, March.

Copeland T.E. and J.F. Weston (1992), Financial theory and corporate policy, New York, Pearson, 1992.

De S. and Singh M. (2009), “Inter-firm credit: Do informal relationships help?", Centre for Analytical Finance, Indian School of Business, Hyderabad, available at http://ssrn.com/abstract $=1362547$.

Dei Ottati G. (1994), "Trust, interlinking transactions and credit in the industrial district", Cambridge Journal of Economics, 18(6) 529-46.

Deloof M. (1998), "Internal capital markets, bank borrowing, and financing constraints: evidence from Belgian firms", Journal of Business Finance and Accounting, 25(7-8), 945-68.

Deloof M. and M. Jegers (1999), "Trade credit, corporate groups and the financing of Belgian firms", Journal of Business Finance and Accounting, 26(7-8), 945-66.

Desai, M.A., C.F. Foley and J.R. Hines (2004), “A multinational perspective on capital structure choice and internal capital markets", Journal of Finance, 59(6), 2451-87.

Dewaelheyns N. and C. Van Hulle (2008), “Internal capital markets and capital structure: Bank versus internal debt", European Financial Management, early view, July. 
Faccio M. (2006), "Politically connected firms", American Economic Review, 96(1), 369-386.

Faccio M., L.H.P. Lang, L. Young (2003), "Debt and expropriation”, EFMA Lugano Meetings. Available at: SSRN: http://ssrn.com/abstract $=239724$.

Fafchamps M. and B. Minten (1999), "Relationships and traders in Madagascar", The Journal of Development Studies, 35(6), 1-35.

Ferguson M.F. and S.R. Peters (1997), "Cultural affinity and lending discrimination: the impact of underwriting errors and credit risk distribution on applicant denial rates, Journal of Financial Services Research, 11(1-2), 153-68.

Fisman R.J.(2003), "Ethnic ties and the provision of credit: Relationship-level evidence from African firms", Advances in Economic Analysis \& Policy, 3(1), Article 4. Available at http://www.bepress.com/bejeap/advances/vol3/iss1/art4.

Friedman E., Johnson S. And T. Mitton (2003), "Propping and tunneling", Journal of Comparative Economics, 31(4), 732-50.

Freixas X. and J.-C. Rochet (1997), Microeconomics of banking, Cambridge, Mass., The MIT Press.

Fulghieri P. and M. Sevilir (2003), "The ownership and financing of innovation in R\&D races", ECGI Finance Working Paper No. 18.

Gangopadhyay S., R. Lensink and R. van der Molen (2003), "Business groups, financing constraints, and investment: The case of India", Research Report 02E02, SOM Research Institute, University of Groningen.

Gautier A. and M. Hamadi (2005), "Internal capital market efficiency of Belgian holding companies", Finance, 26(2), 11-34.

Gertner R.H., D.S. Scharfstein andd J.C. Stein (1994), "Internal versus external capital markets", Quarterly Journal of Economics, 109(4), 1211-30.

Ghatak M. and R. Kali (2001), "Financially Interlinked Business Groups", Journal of Economics and Management Strategy, 10(4), 591-619.

Gonenc H. and N. Hermes (2008), "Propping: Evidence from new share issues of Turkish business group firms", Journal of Multinational Financial Management, 18(3), 261-75.

Gopalan R., V. Nanda and A. Seru (2007), “Affiliated firms and financial support: Evidence from Indian business groups", Journal of Financial Economics, 86(3), 759-95.

Grandori A. and G. Soda (1995), "Inter-firm networks: Antecedents, mechanisms and forms", Organization Studies, 16(2), 183-214.

Granovetter M. (1985), "Economic action and social structure: the problem of embeddedness", American Journal of Sociology, 91, 481-510.

Greif A. (1989) "Reputation and coalitions in medieval trade: Evidence on the Maghribi traders' coalition", Journal of Economic History, 49(4), 857-82. 
Greif A. (1993), "Contract enforceability and economic institutions in early trade: The Maghribi traders' coalition", American Economic Review, 83(3), 525-48.

Guelpa F. and V. Tirri (2006), The effect of market structure and relationship lending on the likelihood of credit tightening, manuscript, Milano, Banca Intesa.

Hainz C. (2006), "Business groups in emerging markets: Financial control and sequential investment," CESifo Working Paper No. 1763.

Hart O. (1995), Firms contracts and financial structure, Oxford: Oxford University Press.

Hermes N. and R. Lensink (1998), "Regulatory change and the allocation of finance: the role of business conglomerates in Chile, 1983-1992" in V. Murinde, J.Doukas and C. Wihlborg (eds), Financial sector reform and privatization in transition economies, North Holland.

Himmelberg C.P. and B.C. Petersen (1994), "R\&D and internal finance: A panel study of small firms in high-tech industries", Review of Economics and Statistics, 76 (1), 38-51.

Hoshi T., A. Kashyap and D. Scharfstein (1991), "Corporate structure, liquidity, and investment: Evidence from Japanese industrial groups", Quarterly Journal of Economics, 106(1), 33-60.

Jackson M.O. (2008), Social and economic networks, Princeton University Press

Johnson S., R. La Porta, F. Lopez-de-Silanes and A. Shleifer (2000), "Tunneling", American Economic Review Papers and Proceedings, 90(2), 22-27.

Kali R. (1999), "Endogenous business networks", Journal of Law, Economics \& Organizations, 15(3), 615-36.

Khanna T. and K. Palepu (2000), "Is group affiliation profitable in emerging markets? An analysis of diversified Indian business groups", Journal of Finance, 55(2), 867-91.

Khanna T. and J.W. Rivkin (2006), "Interorganizational ties and business group boundaries: Evidence from an emerging economy”, Organization Science, 17(4), 333-52.

Khanna T. and C. Thomas (2009), "Synchronicity and firm interlocks in an emerging market", Journal of Financial Economics, 92(2), 182-204.

Khanna T. and S. Tice (2001), "The bright side of internal capital markets", Journal of Finance, 56(4), 1489-531.

Khanna T. and Y. Yafeh (2005), "Business groups and risk sharing around the world", Journal of Business, 78(1), 301-40.

Kim S.-E. (2004), "Bailout and conglomeration”, Journal of Financial Economics, 71(2), 315-47.

Kim H., A. Heshmati and D. Aoun (2006), "Dynamics of capital structure: The case of Korean listed manufacturing companies" Asian Economic Journal, 20 (3): 275-302.

Kranton R. (1996), "Reciprocal exchange: A self-sustaining system" American Economic Review, $86(4), 830-851$. 
Kumar R.S. and M.H.B. Subrahmanya (2008), "Subcontracting relationship of Indian SMEs with a global TNC: Do SMEs gain? How?”, Department of Management Studies, Indian Institute of Science.

Lamont O. (1997), "Cash-flow and investment: Evidence from internal capital markets", Journal of Finance, 52(1), 83-109.

Lang L. and R. Stultz (1994), “Tobin's q, corporate diversification, and firm performance”, Journal of Political Economy 102, 1248-80.

La Porta R., F. Lopez-de-Silanes and A. Shleifer (1999), "Corporate ownership around the World. Journal of Finance, 54(2), 471-517.

Lee S., K. Park and H.H. Shin (2009), "Disappearing internal capital Markets: Evidence from diversified business groups in Korea”, Journal of Banking \& Finance, 33(2), 326-34.

Lizal L. and J. Svejnar (2002), "Investment, credit rationing, and the soft budget constraint: Evidence from Czech panel data”, Review of Economics and Statistics”, 84(2), 353-70.

Maksimovic V. and G. Phillips (2002), "Do conglomerate firms allocate resources inefficiently across industries? Theory and evidence", Journal of Finance, 57(2), 721-67.

Manos R., V. Murinde and C.J. Green (2007), "Leverage and business groups: Evidence from Indian firms", Journal of Economics and Business, 59(5), 443-65.

Marchionne F. and A. Zazzaro (2008), "Accesso al mercato del credito, struttura del capitale e gruppi di imprese", in A. Zazzaro (ed.), I vincoli finanziari alla crescita delle imprese, Roma, Carocci.

Mathews R.D. and D.T. Robinson (2008), "Market structure, internal capital markets, and the boundaries of the firm", Journal of Finance 63(6), 2703-36.

Matsusaka J.G. and V. Nanda (2002), "Internal capital markets and corporate refocusing”, Journal of Financial Intermediation, 11, 176-211.

McMillan J. and C. Woodruff (1999), "Interfirm relationships and informal credit in Vietnam", Quarterly Journal of Economics, 114(4), 1285-320.

Menard C. (2004), “The economics of hybrid organizations", Journal of Institutional and Theoretical Economics, 160(3), 345-76.

Mizruchi M.S. and L.B. Stearns (1994), “A longitudinal study of borrowing by large American corporations", Administrative Science Quarterly, 39, 118-40.

Mizruchi M.S., L.B. Stearns and C. Marquis (2005), "The conditional nature of embeddedness: A study of borrowing by large U.S. Firms, 1973-1994", American Sociological Review, 71(2), 31033.

Mullainathan S. and D. Scharfstein (2001), "Do Firm Boundaries Matter?", American Economic Review, 91(2), 195-99. 
Natividad G. (2009), “The Organizational Efficiency of Internal Capital Markets”, AFA 2009 San Francisco Meetings paper.

Ozbas O. and D.S. Scharfstein (2009), "Evidence on the Dark Side of Internal Capital Markets", Review of Financial Studies, forthcoming.

Pagnini M. (2000), "I vincoli finanziari per le imprese distrettuali”, in F.L. Signorini (ed.), Lo sviluppo locale, Roma, Donzelli.

Perotti E.C. and S. Gelfer (2001), "Red barrons or robber barons? Governance and investment in Russian financial-industrial groups", European Economic Review, 45, 1601-17

Piga C. A.G. (2002), “Debt and firms' relationships: The Italian evidence”, Review of Industrial Organization, 20(3), 267-82.

Powell W.W. (1990), “Neither Markets nor Hierarchy: Network forms of organisation”, in L.L. Cummings and B. Shaw (eds), Research in organisational behaviour, Greenwich, JAI Press.

Rajan R., H. Servaes and L. Zingales (2000), “The cost of diversity: The diversification discount and inefficient investment" Journal of Finance 55(1), 35-80.

Reimund C. (2002), Internal capital markets, bank borrowing and investment: Evidence from German corporate groups, manuscript, Leipzig Graduate School of Management.

Rejie G. and K. Rezaul (2008), "Business groups and profit redistribution: A boon or bane for firms?"

Journal of Business Research, 61(9), 1004-14.

Rejie P., K. Rezaul and Q. Jing (2008), "Investment - Cash Flow Sensitivity and Financing Constraints: An Analysis of Indian Business Group Firms", available at SSRN: http:/ /ssrn.com/abstract $=683725$.

Robinson D.T. (2008), "Strategic alliances and the boundaries of the firm", Review of Financial Studies, 21(2), 649-81.

Roland G. (2000), Transition and economics: Politics, markets and firms, Cambridge, Mass., MIT Press.

Rotondi Z. (2005), "Banche, finanziamento allo sviluppo e dell'innovazione e internazionalizzazione", in G. Bracchi and D. Masciandaro (eds.), Decimo rapporto SFI. Le banche italiane e la finanza per lo sviluppo: territori, imprese e famiglie, Roma, Fondazione Rosselli Edibank.

Russo P.F. and P. Rossi (2001), "Credit constraints in Italian industrial districts", Applied Economics, 33(11), 1469-77.

Sabetta A. (2009), Le prospettive dei confidi meridionali, manuscript, Roma, Università "Tor Vergata". Samphantharak K. (2003), Internal Capital Markets in Business Groups manuscript, Department of Economics, University of Chicago. 
Scalera D. and A. Zazzaro (2001), "Group reputation and persistent (or permanent) discrimination in credit markets", Journal of Multinational Financial Management, 11(4-5), 483-96.

Scharfstein D.S. (1998), "The dark side of internal capital markets II: Evidence from diversified conglomerates", NBER Working Paper 6352.

Scharfstein D.S. and J.S. Stein (2000), “The dark side of internal capital markets: Divisional rentseeking and inefficient investment" Journal of Finance 55(6), 2537-64.

Schiantarelli F. and A. Sembenelli (2000), "Form of ownership and financial constraints: Panel data evidence from flow of funds and investment equations", Empirica, 27(2), 175-92.

Shane S. and D. Cable (2002), "Network ties, reputation, and the financing of new ventures" Management Science, 48, 364-81.

Shin H.H. and Y.S. Park (1999), "Financing constraints and internal capital markets: Evidence from Korean 'chaebols"', Journal of Corporate Finance, 5(2), 169-91.

Shin H.H. and Stultz R.M. (1998), “Are internal capital markets efficient?”, Quarterly Journal of Economics, 113(2), 531-52.

Silva F., N. Majluf and R.D. Paredes (2006), "Family ties, interlocking directors and performance of business groups in emerging countries: The case of Chile" Journal of Business Research, 59(3), $315-21$

Sorenson O. and T.E. Stuart (2001), "Syndication networks and the spatial distribution of venture capital investment”, American Journal of Sociology, 106(6), 1546-88.

Stearns L.B. and M.S. Mizruchi (1993), "Board composition and corporate financing: The impact of financial institution representation on borrowing", Academy of Management Journal, 36, 60318.

Stein J.C. (1997), "Internal capital markets and the competition for corporate resources", Journal of Finance, 52(1), 111-33.

Stein J. (2003), “Agency, information and corporate investment”, in G. Constantinides, M. Harris and R. Stulz (eds), Handbook of the Economics of Finance, vol. I, Amsterdam: North Holland.

Taylor (2000), "The old-boy network and the young-gun effect", International Economic Review, 41(4), 871-91.

Ughetto E. (2007), “Industrial districts and financial constraints to innovation”, Innovation Studies Working Paper 3.

Uzzi B. (1999), "Social relations and networks in the making of financial capital", American Sociological Review, 64, 481-505.

Uzzi B. and R. Lancaster (2003), "Relational embeddedness and learning: The case of bank loan managers and their clients, Management Science, 49(4), 383-99. 
Uzzi B. and R. Lancaster (2003), "Relational embeddedness and learning: The case of bank loan managers and their clients", Management Science, 49(4), 383-99.

Williamson O. (1975), Markets and Hierarchies: Analysis and Antitrust Implications: A Study in the Economics of Internal Organization, New York: Free Press.

Wulf J. (2005), Influence and inefficiency in the internal capital market, manuscript, Wharton School, University of Pennsylvania. 
Figure 1: The governance structure of the inter-firm network

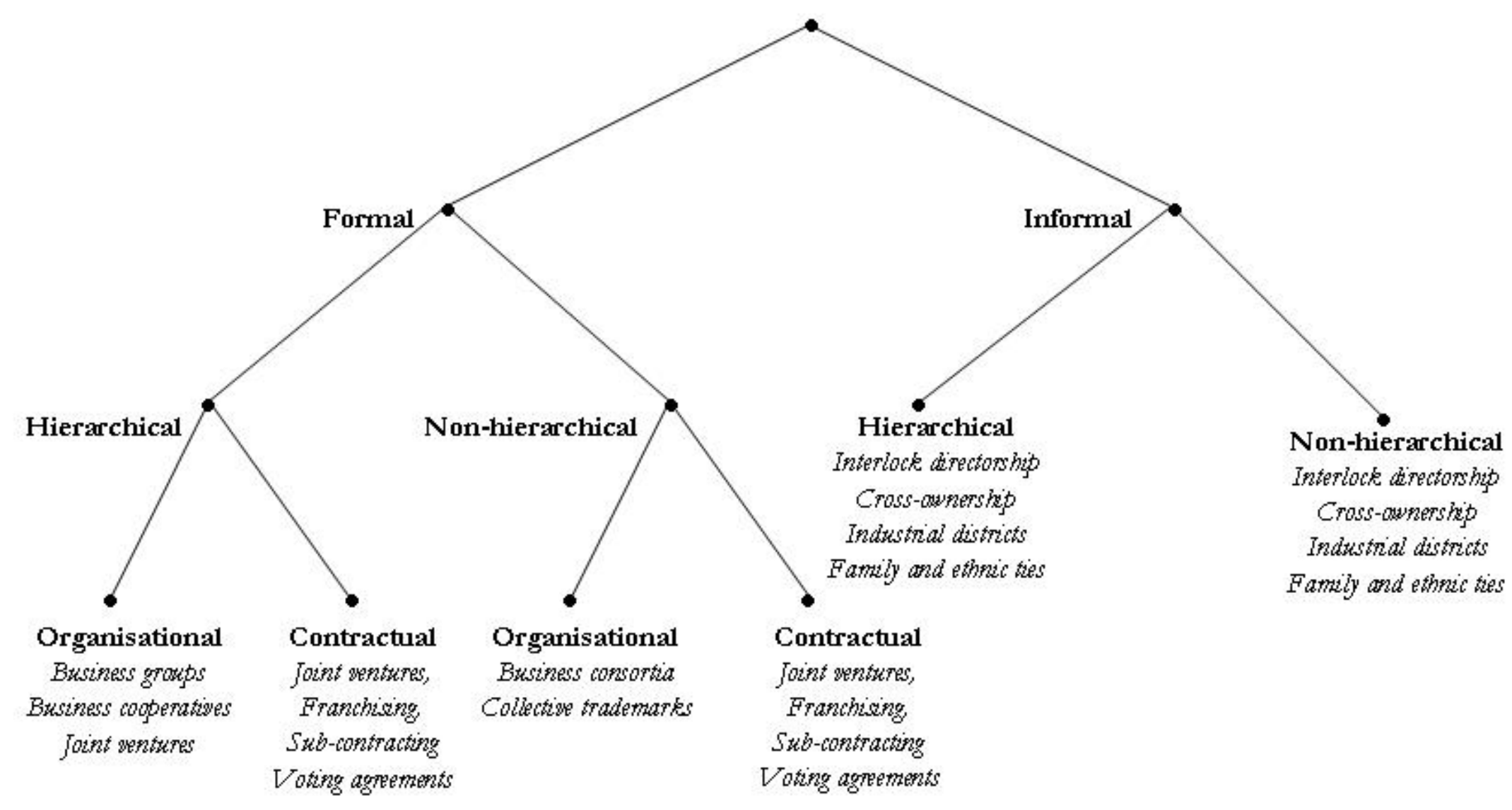


Table 1: Costs and benefits of network membership for corporate finance

\begin{tabular}{lll}
\hline \multicolumn{1}{c}{ Benefits } & \multicolumn{1}{c}{ Costs } \\
\hline - Internal capital market & Explicit/implicit debt & Internal capital market and \\
& guarantees & conflict of interests \\
- Good network reputation & - Tunneling \\
- Bargaining power & - Rent seeking \\
& & - Free riding \\
& & Bad network reputation \\
\hline
\end{tabular}

